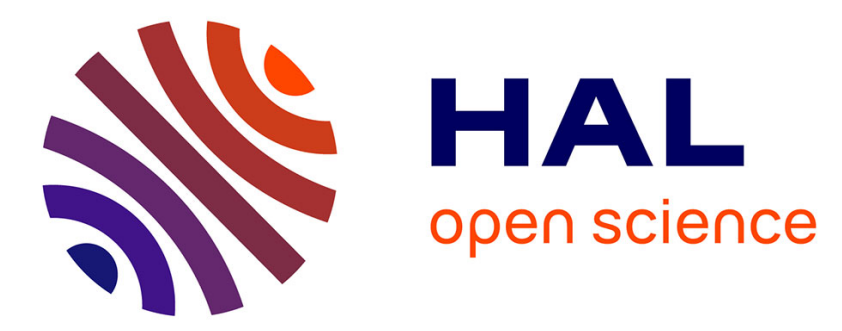

\title{
Human Papillomavirus type distribution in Vulval Intraepithelial Neoplasia determined using PapilloCheck DNA microarray
}

Dean Bryant, Nirmala Rai, Gareth Lloyd Rowlands, Sam Hibbitts, Joanne Jones, Amanda Tristram, Alison Fiander, Ned Powell

\section{To cite this version:}

Dean Bryant, Nirmala Rai, Gareth Lloyd Rowlands, Sam Hibbitts, Joanne Jones, et al.. Human Papillomavirus type distribution in Vulval Intraepithelial Neoplasia determined using PapilloCheck DNA microarray. Journal of Medical Virology, 2011, 83 (8), pp.1358. 10.1002/jmv.22107 . hal00645108

\section{HAL Id: hal-00645108 \\ https://hal.science/hal-00645108}

Submitted on 26 Nov 2011

HAL is a multi-disciplinary open access archive for the deposit and dissemination of scientific research documents, whether they are published or not. The documents may come from teaching and research institutions in France or abroad, or from public or private research centers.
L'archive ouverte pluridisciplinaire $\mathbf{H A L}$, est destinée au dépôt et à la diffusion de documents scientifiques de niveau recherche, publiés ou non, émanant des établissements d'enseignement et de recherche français ou étrangers, des laboratoires publics ou privés. 


\section{Human Papillomavirus type distribution in Vulval Intraepithelial Neoplasia determined using PapilloCheck DNA microarray}

\begin{tabular}{|r|l|}
\hline Journal: & Journal of Medical Virology \\
\hline Manuscript ID: & JMV-11-2313.R1 \\
\hline Wiley - Manuscript type: & Research Article \\
\hline Date Submitted by the & 22-Mar-2011 \\
\hline Complete List of Authors: & $\begin{array}{l}\text { Bryant, Dean; School of Medicine, Cardiff University, Obstetrics and } \\
\text { Gynaecology } \\
\text { Rai, Nirmala; School of Medicine, Cardiff University, Obstetrics and } \\
\text { Gynaecology } \\
\text { Rowlands, Gareth; University Hospital of Wales, Pathology } \\
\text { Hibbitts, Sam; School of Medicine, Cardiff University, Obstetrics and } \\
\text { Gynaecology } \\
\text { Jones, Joanne; School of Medicine, Cardiff University, Obstetrics } \\
\text { and Gynaecology } \\
\text { Tristram, Amanda; School of Medicine, Cardiff University, Obstetrics } \\
\text { and Gynaecology } \\
\text { Fiander, Alison; School of Medicine, Cardiff University, Obstetrics } \\
\text { and Gynaecology } \\
\text { Powell, Ned; School of Medicine, Cardiff University, Obstetrics and } \\
\text { Gynaecology }\end{array}$ \\
\hline Keywords: & $\begin{array}{l}\text { HPV, Human papillomavirus, VIN, Vulval intraepithelial neoplasia, } \\
\text { Papillocheck }\end{array}$ \\
\hline \hline
\end{tabular}

\section{SCHOLARONE $^{\text {th }}$ \\ Manuscripts}


1 Human Papillomavirus type distribution in Vulval Intraepithelial Neoplasia 2 determined using PapilloCheck DNA microarray

4 Dean Bryant, Nirmala Rai, Gareth Rowlands, Sam Hibbitts, Joanne Jones, Amanda

5 Tristram, Alison Fiander, Ned Powell*

6

7 HPV Research Group, Obstetrics and Gynaecology, School of Medicine, Cardiff

8 University, CF14 4XN

9

$10 *$ Correspondence to:

11 Dr Ned Powell

12 Obstetrics and Gynaecology

13 School of Medicine

14 Cardiff University

15 Heath Park

16 CF14 4XN

17 Email: powellng@cf.ac.uk

18

19 Short title: HPV type distribution in vulval intraepithelial neoplasia 


\section{Abstract}

21 Vulval intraepithelial neoplasia is a precursor of vulval carcinoma, and is frequently

22 associated with Human Papillomavirus (HPV) infection. Estimates of HPV

23 prevalence in vulval intraepithelial neoplasia vary widely in the UK. The objective of

24 this study was to assess HPV infection in a sample of women with vulval

25 intraepithelial neoplasia, confirmed histologically, and determine the proportion of

26 disease associated with HPV types targeted by prophylactic HPV vaccines. HPV

27 infection was assessed in biopsies from 59 patients using the Greiner Bio-One

28 PapilloCheck ${ }^{\circledR}$ DNA chip assay. Valid results were obtained for 54 cases. HPV

29 infection was present in 43 of the 54 cases (79.6\%: 95\% CI 67.1-88.2\%). The most

30 common HPV types were HPV 16 (33/54: 61.1\%), HPV 33 (8/54: 14.8\%), HPV 6

31 (5/54: $9.3 \%)$ and HPV 42 (3/54: 5.6\%). The mean age of HPV positive women was

32 significantly less than the mean age of HPV negative women.

33 This is the largest UK series of vulval intraepithelial neoplasia in which HPV type has

34 been investigated, and 34/54 (63.0\%, 95\% CI: 49.6-78.6\%) cases were associated

35 with HPV 16/18, which are targeted by current prophylactic HPV vaccines.

37 Key words

38 HPV, Human papillomavirus, VIN, Vulval intraepithelial neoplasia, Papillocheck 
39

40

41

42

43

44

45

46

47

48

49

50

51

52

53

56

54 PapilloCheck ${ }^{\circledR}$ DNA chip assay and determine the proportion of vulval intraepithelial 55 neoplasia potentially preventable by HPV prophylactic vaccination.

\section{INTRODUCTION}

Vulval intraepithelial neoplasia is frequently a painful, distressing condition, and a precursor lesion of invasive vulval carcinoma. In recent decades the incidence of vulval intraepithelial neoplasia has increased, while the mean age of patients has decreased. The incidence of vulval cancer rose by $17 \%$ between 1979 and 2001 [MacLean, 2004], with 996 new cases registered in England in 2000 [MacLean, 2006].

Human Papillomavirus (HPV) positivity in vulval intraepithelial neoplasia lesions is reported in international meta-analyses as $84 \%$ with most cases attributable to HPV type 16 [De Vuyst et al., 2009]. The most likely explanation for the increased incidence of vulval intraepithelial neoplasia is the substantial rise in HPV infections of the lower genital tract [Peto et al., 2004]; the lifetime risk of HPV infection being estimated at up to $79 \%$ [Syrjanen et al., 1990].

2 The aim of this investigation was to identify HPV types present in vulval

3 intraepithelial neoplasia, confirmed histologically, using the Greiner Bio-One 


\section{MATERIALS AND METHODS}

\section{Study population}

The study population comprised women attending a specialist vulval intraepithelial neoplasia clinic at the University Hospital of Wales, Cardiff, UK between 2003 and 2009, with vulval intraepithelial neoplasia confirmed histologically, who gave written informed consent for a biopsy to be taken for research purposes. The study was approved by South Wales LREC (SMKW/EL/03/5178). 59 cases were investigated, with an age range of 22-82 years, and a mean age of 45.8 years. There were six cases of vulval intraepithelial neoplasia grade 1, two of vulval intraepithelial neoplasia grade 2 , and fifty one cases of vulval intraepithelial neoplasia grade 3.

\section{Sample collection and processing.}

Separate biopsies were taken for histology and research use. The research biopsy was immediately placed in liquid based cytology medium (which fixed cells and preserved DNA). DNA was extracted from the research biopsy using the Qiagen QIAamp kit (QIAGEN GmbH, Hilden, Germany) according to the manufacturer's instructions.

\section{Pathology review}

A recent review of vulval intraepithelial neoplasia histopathology recommended replacement of the vulval intraepithelial neoplasia 1/2/3 subdivisions with two categories reflecting the putative aetiology of the disease: usual vulval intraepithelial neoplasia (HPV-associated); and differentiated vulval intraepithelial neoplasia (associated with lichen sclerosis) [Sideri et al., 2005]. However, the existence of differentiated vulval intraepithelial neoplasia is disputed, and in practice this diagnosis is rarely made [McCluggage, 2009]. The histopathology of lesions in this study is 
82 reported using both the vulval intraepithelial neoplasia $1 / 2 / 3$ and usual/differentiated

83 classification. Pathology review was undertaken blind to HPV status by an

84 experienced Consultant Histopathologist with a special interest in gynaecological 85 pathology (GR).

86

$87 \quad$ PapilloCheck ${ }^{\circledR}$ assay

88 HPV infection was identified using the Greiner Bio-One Papillocheck ${ }^{\circledR}$ assay (Greiner 89 Bio-One GmbH, Frickenhausen, Germany), which enables simultaneous detection and 90 typing of 24 different HPV types in a single reaction (HPV 16, 18, 31, 33, 35, 39, 45, $9151,52,53,56,58,59,66,68,70,73,82,6,11,40,42,43 \& 44)$. The assay uses 92 multiplex PCR with fluorescent primers to amplify a 350bp fragment of the E1 gene.

93 The PCR product is then hybridised to a PapilloCheck ${ }^{\circledR}$ DNA array, comprising 28

94 probes, each in 5 replicate spots. To identify false negatives the assay includes

95 amplification of the human ADAT1 gene. Hybridization is assessed using the

96 CheckScanner ${ }^{\mathrm{TM}}$ array reader. Amplification, hybridization, detection and

97 interpretation were performed according to the manufacturer's instructions. A valid

98 result was defined as one which passed all of the PapilloCheck ${ }^{\circledR}$ internal controls

99 (including DNA adequacy, sample inhibition, and hybridisation).

100 Previous studies have confirmed the analytical [Dalstein et al., 2009; Jones et al.,

101 2009] and clinical validity [Halfon et al., 2009; Hesselink et al., 2009] of this assay in

102 large sample sets as compared to GP5+/6+, HC2 and Roche Linear Array. The assay

103 is certified within the European Union as an in vitro diagnostic for qualitative

104 detection of HPV in clinical specimens. 


\section{7 \\ RESULTS}

\section{HPV type distribution}

109 HPV type distribution, stratified by histology, is shown in Table I. Valid results were

110 obtained for 54 of the 59 cases. HPV infection was present in 43/54 cases (79.6\%:

$11195 \%$ CI 67.1-88.2\%). HPV 16 and/or 18 were present in 34/54 cases $(63.0 \%, 95 \%$

112 CI: 49.6-78.6\%). HPV 16 and/or 18 were the only types present in 26/54 cases (48\%,

113 95\% CI: $35.4-61.2 \%)$.

114 High Risk (HR) HPV types were present in 38 cases and Low Risk (LR) types in 9

115 cases; 4 cases contained both HR and LR types. Multiple HPV types were present in

11610 cases; in these cases the distribution of types was: one vulval intraepithelial

117 neoplasia grade 1 sample contained HPV 18, 42 and 44/55; all other cases with

118 multiple types were vulval intraepithelial neoplasia 3 and the combinations of types

119 were: 3 cases with HPV 16 and 33; 2 cases with HPV 16 and 6; and one case each of

$120(16,18),(33,42),(16,31,33),(16,51)$. In the 5 cases where only LR types were

121 present, 3 were HPV 6 (histology: two cases of vulval intraepithelial neoplasia grade

1223 , and one vulval intraepithelial neoplasia grade 3 with well-differentiated carcinoma

123 and viral warts), 1 was HPV 40 (vulval intraepithelial neoplasia 1) and 1 contained

124 HPV 42 (vulval intraepithelial neoplasia 1).

125

126 HPV and age

127 HPV positive cases were aged 22-81 with a mean of 43.4 years. HPV negative cases

128 were aged 33-82 years with a mean of 54.9 years. The means of these groups were

129 significantly different $(\mathrm{t}$ test $\mathrm{p}=0.019)$.

130

$131 \quad$ HPV and histology 
132 There was no significant correlation between HPV positivity and grade of lesion. Of

133 the HPV positive cases, 40/43 (93.0\%) showed vulval intraepithelial neoplasia grade 2

134 or worse. This was slightly lower in HPV negative lesions, where 9/11 (81.8\%)

135 showed vulval intraepithelial neoplasia grade 2 or worse, but this difference was not

136 significant (Fisher's $\mathrm{P}=0.266$ ).

137 There was no significant correlation between HPV type and histological grade;

138 however it was noticeable that all of the HPV 16 positive cases were associated with

139 vulval intraepithelial neoplasia 2 or worse, while a high risk type (HPV 18) was

140 identified in only $1 / 5$ vulval intraepithelial neoplasia grade 1 cases with valid HPV

141 results.

142 Slides were available for pathology review for 54/59 cases. 52/54 cases were "Usual

143 vulval intraepithelial neoplasia"; 2/54 cases were "Probable Differentiated vulval

144 intraepithelial neoplasia". Both cases of probable Differentiated vulval intraepithelial

145 neoplasia were in HPV negative patients: one an 82 year old woman with vulval

146 intraepithelial neoplasia 3, the other a 61 year old woman with vulval intraepithelial

147 neoplasia 1 (but with a history of vulval cancer). Among the cases with valid HPV

148 results, 42/49 cases of usual vulval intraepithelial neoplasia were HPV positive

149 (85.7\% 95\%CI: 73.3-92.9\%). 
150

151 This is the largest UK series of vulval intraepithelial neoplasia in which HPV type has

152 been determined. The main limitation of this study was the use of a self selected

153 sample, i.e. women attending a specialist vulval intraepithelial neoplasia clinic. This

154 might bias the sample towards women with persistent or recurrent disease, which

155 might possibly result in some over-representation of more persistent types (HPV 16).

156 A further limitation was the use of separate biopsies for pathology and HPV analysis;

157 in practice both biopsies were immediately adjacent and cases were only included if

158 both biopsies were part of the same macroscopically visible lesion. It is however

159 theoretically possible that the research biopsy may not be representative of the

160 diagnostic biopsy.

161

162 Several studies have investigated HPV prevalence in vulval intraepithelial neoplasia

163 in the UK and estimate HPV positivity at 37.5 to $100 \%$, with the proportion of HPV

164 positive cases containing HPV 16 varying from 37.5 to 93.3\% [Abdel-Hady et al.,

165 2001; Baldwin et al., 2003; Daayana et al., 2010; Fiander et al., 2006; Gasco et al.,

166 2002; Todd et al., 2002; Tristram and Fiander, 2005; Woo et al., 2007]. The sample

167 size in these studies ranged from 8-29 cases. The sample size for the current study is

168 larger, and the findings are more consistent with the overall results of a recent

169 international meta-analysis, in which $84.0 \%$ of vulval intraepithelial neoplasia cases

170 tested HPV positive (67.5\% were HPV 16, 7.7\% were HPV 33, and 4.6\% were HPV

171 18) [De Vuyst et al., 2009]. The corresponding proportions in the current study were

172 overall HPV positivity of $79.6 \%$ (61.1 \% were positive for HPV 16, $14.8 \%$ for HPV

17333 , and 3.7\% for HPV 18). These are also similar to a separate meta-analysis which 
174 indicated an overall HPV positivity of $80.4 \%$ for vulval intraepithelial neoplasia $2 / 3$

175 (HPV 16 present in 71.2\%, HPV33 in 7.7\% and HPV 18 in 5.5\% [Smith et al., 2009]).

176 Patients who tested positive for HPV infection were significantly younger (by over 11

177 years on average) than those testing negative. This is consistent with HPV associated

178 disease being more common in younger women and vulval intraepithelial neoplasia

179 associated with lichen sclerosis being more common in older patients [Bonvicini et

180 al., 2005].

181 The finding that $85.7 \%$ of usual vulval intraepithelial neoplasia were HPV positive is

182 in accord with data previously reviewed [van de Nieuwenhof et al., 2008]. The 7 HPV

183 negative usual vulval intraepithelial neoplasia patients represent an interesting group;

184 it is not clear whether these patients are accounted for by mis-diagnosis of

185 differentiated vulval intraepithelial neoplasia (possibly due to sampling error), or

186 whether there is a subset of usual vulval intraepithelial neoplasia that is truly HPV

187 negative.

188

189 Three cases showing vulval intraepithelial neoplasia grade 2 or worse were associated

190 with a low risk HPV type alone (HPV6). One of these cases showed vulval

191 intraepithelial neoplasia grade 3 with well differentiated squamous cell carcinoma and

192 viral warts; it is possible that the warts were associated with the HPV 6 but the vulval

193 intraepithelial neoplasia and carcinoma were not. This apparent association between

194 high grade vulval intraepithelial neoplasia and LR HPV types runs contrary to the

195 suggestion that LR types cause only warts and low grade lesions. However an

196 association between LR HPV types and high grade disease was observed in the De

197 Vuyst meta analysis [De Vuyst et al., 2009] which reported approximately 5\% of

198 vulval intraepithelial neoplasia 2/3 as linked to HPV 6. 
199

200 HPV associated vulval intraepithelial neoplasia is most common in women in their

20130 's and 40's [Hart, 2001]. The incidence of VIN is approximately 5 per 100,000

202 women per year and is increasing [Joura, 2002]. HPV infection is endemic in the UK

203 with almost $30 \%$ of women in the $20-25$ year age range now infected with a high risk

204 anogenital HPV type [Hibbitts et al., 2008]. Hence, in the short term, the number of

205 women affected by vulval intraepithelial neoplasia is likely to continue increasing.

206 HPV vaccination has been shown to be $100 \%$ effective in prevention of vulval

207 epithelial neoplasia 2/3 associated with HPV 16/18 in a per protocol population [Joura

208 et al., 2007]. In the UK vaccination of 12-13 year old girls against HPV 16/18

209 infection began in 2008. Hence it is likely to be 20 to 30 years before the effects of

210 this intervention become apparent in reduced incidence of vulval intraepithelial

211 neoplasia. Ultimately however, as HPV 16/18 were present in $63.0 \%$ of vulval

212 intraepithelial neoplasia, our data suggest that greater than half of vulval

213 intraepithelial neoplasia cases could be potentially prevented by vaccination. 


\section{Acknowledgements}

216 DB is grateful for support by a Cancer Research Wales Studentship Award.

217 Funding: The consumables for this study were provided free of charge by Greiner

218 Bio-One GmbH, Frickenhausen, Germany.

219 Competing interests: None declared.

220 


\section{References}

222

223

224

225

226

227

228

229

230

231

232

233

234

235

236

237

238

239

240

241

242

243

244

245

246

247

248

249

250

251

252

253

254

255

256

257

258

259

260

261

262

263

264

265

266

267

268

Abdel-Hady ES, Martin-Hirsch P, Duggan-Keen M, Stern PL, Moore JV, Corbitt G, Kitchener HC, Hampson IN. 2001. Immunological and viral factors associated with the response of vulval intraepithelial neoplasia to photodynamic therapy. Cancer Res 61:192-196.

Baldwin PJ, van der Burg SH, Boswell CM, Offringa R, Hickling JK, Dobson J, Roberts JS, Latimer JA, Moseley RP, Coleman N, Stanley MA, Sterling JC. 2003. Vaccinia-expressed human papillomavirus 16 and 18 e6 and e7 as a therapeutic vaccination for vulval and vaginal intraepithelial neoplasia. Clin Cancer Res 9:5205-5213.

Bonvicini F, Venturoli S, Ambretti S, Paterini P, Santini D, Ceccarelli C, Zerbini M, Musiani M. 2005. Presence and type of oncogenic human papillomavirus in classic and in differentiated vulvar intraepithelial neoplasia and keratinizing vulvar squamous cell carcinoma. J Med Virol 77:102-106.

Daayana S, Elkord E, Winters U, Pawlita M, Roden R, Stern PL, Kitchener HC. 2010. Phase II trial of imiquimod and HPV therapeutic vaccination in patients with vulval intraepithelial neoplasia. Br J Cancer 102:1129-1136.

Dalstein V, Merlin S, Bali C, Saunier M, Dachez R, Ronsin C. 2009. Analytical evaluation of the PapilloCheck test, a new commercial DNA chip for detection and genotyping of human papillomavirus. J Virol Methods 156:77-83.

De Vuyst H, Clifford GM, Nascimento MC, Madeleine MM, Franceschi S. 2009. Prevalence and type distribution of human papillomavirus in carcinoma and intraepithelial neoplasia of the vulva, vagina and anus: a meta-analysis. Int $\mathbf{J}$ Cancer 124:1626-1636.

Fiander AN, Tristram AJ, Davidson EJ, Tomlinson AE, Man S, Baldwin PJ, Sterling JC, Kitchener HC. 2006. Prime-boost vaccination strategy in women with high-grade, noncervical anogenital intraepithelial neoplasia: clinical results from a multicenter phase II trial. Int J Gynecol Cancer 16:1075-1081.

Gasco M, Sullivan A, Repellin C, Brooks L, Farrell PJ, Tidy JA, Dunne B, Gusterson B, Evans DJ, Crook T. 2002. Coincident inactivation of 14-3-3sigma and p16INK4a is an early event in vulval squamous neoplasia. Oncogene 21:18761881.

Halfon P, Benmoura D, Khiri H, Penaranda G, Blanc B, Riggio D, Sandri MT. 2009. Comparison of the clinical performance of carcinogenic HPV typing of the Linear Array and Papillocheck((R)) HPV-screening assay. J Clin Virol. 47:3842.

Hart WR. 2001. Vulvar intraepithelial neoplasia: historical aspects and current status. Int J Gynecol Pathol 20:16-30.

Hesselink AT, Heideman DA, Berkhof J, Topal F, Pol RP, Meijer CJ, Snijders PJ. 2010. Comparison of the clinical performance of the PapilloCheck HPV detection with GP5+/6+-PCR-EIA in population-based cervical screening. J Clin Microbiol. 48:797-801

Hibbitts S, Jones J, Powell N, Dallimore N, McRea J, Beer H, Tristram A, Fielder H, Fiander AN. 2008. Human papillomavirus prevalence in women attending routine cervical screening in South Wales, UK: a cross-sectional study. Br J Cancer 99:1929-1933.

Jones J, Powell NG, Tristram A, Fiander AN, Hibbitts S. 2009. Comparison of the PapilloCheck DNA microarray Human Papillomavirus detection assay with 
Hybrid Capture II and PCR-enzyme immunoassay using the GP5/6+ primer set. J Clin Virol 45:100-104.

Joura EA. 2002. Epidemiology, diagnosis and treatment of vulvar intraepithelial neoplasia. Curr Opin Obstet Gynecol 14:39-43.

Joura EA, Leodolter S, Hernandez-Avila M, Wheeler CM, Perez G, Koutsky LA, Garland SM, Harper DM, Tang GWK, Ferris DG, Steben M, Jones RW, Bryan J, Taddeo FJ, Bautista OM, Esser MT, Sings HL, Nelson M, Boslego JW, Sattler C, Barr E, Paavonen J. 2007. Efficacy of a quadrivalent prophylactic human papillomavirus (types $6,11,16$, and 18) L1 virus-likeparticle vaccine against high-grade vulval and vaginal lesions: a combined analysis of three randomised clinical trials. The Lancet 369:1693-1702.

MacLean AB. 2004. Vulval cancer: the past 100 years, and into the next century: the Presidential Oration, British Society for the Study of Vulval Disease, 2002. J Obstet Gynaecol 24:491-497.

MacLean AB. 2006. Vulval cancer: prevention and screening. Best Pract Res Clin Obstet Gynaecol 20:379-395.

McCluggage WG. 2009. Recent developments in vulvovaginal pathology. Histopathology 54:156-173.

Peto J, Gilham C, Fletcher O, Matthews FE. 2004. The cervical cancer epidemic that screening has prevented in the UK. Lancet 364:249-256.

Sideri M, Jones RW, Wilkinson EJ, Preti M, Heller DS, Scurry J, Haefner H, Neill S. 2005. Squamous vulvar intraepithelial neoplasia: 2004 modified terminology, ISSVD Vulvar Oncology Subcommittee. J Reprod Med 50:807-810.

Smith JS, Backes DM, Hoots BE, Kurman RJ, Pimenta JM. 2009. Human papillomavirus type-distribution in vulvar and vaginal cancers and their associated precursors. Obstet Gynecol 113:917-924.

Syrjanen K, Hakama M, Saarikoski S, Vayrynen M, Yliskoski M, Syrjanen S, Kataja V, Castren O. 1990. Prevalence, incidence, and estimated life-time risk of cervical human papillomavirus infections in a nonselected Finnish female population. Sex Transm Dis 17:15-19.

Todd RW, Etherington IJ, Luesley DM. 2002. The effects of 5\% imiquimod cream on high-grade vulval intraepithelial neoplasia. Gynecol Oncol 85:67-70.

Tristram A, Fiander A. 2005. Clinical responses to Cidofovir applied topically to women with high grade vulval intraepithelial neoplasia. Gynecol Oncol 99:652-655.

van de Nieuwenhof HP, van der Avoort IA, de Hullu JA. 2008. Review of squamous premalignant vulvar lesions. Crit Rev Oncol Hematol 68:131-156.

Woo YL, Damay I, Stanley M, Crawford R, Sterling J. 2007. The use of HPV Linear Array Assay for multiple HPV typing on archival frozen tissue and DNA specimens. J Virol Methods 142:226-230. 


\begin{tabular}{|l||r|r|r|r|r|r|r|r|r|}
\hline \multicolumn{1}{|c||}{ Histology } & 16 & 18 & 31 & 33 & 51 & 6 & 40 & 42 & $44 / 55^{*}$ \\
\hline \hline VIN 1 & 0 & 1 & 0 & 0 & 0 & 0 & 1 & 2 & 1 \\
\hline VIN 2 & 1 & 0 & 0 & 0 & 0 & 1 & 0 & 0 & 0 \\
\hline VIN 3 & 32 & 1 & 1 & 8 & 1 & 4 & 0 & 1 & 0 \\
\hline \hline Total & 33 & 2 & 1 & 8 & 1 & 5 & 1 & 3 & 1 \\
\hline$\%$ & 61.1 & 3.7 & 1.9 & 14.8 & 1.9 & 9.3 & 1.9 & 5.6 & 1.9 \\
\hline
\end{tabular}

Table I. HPV type distribution within histological grade.

There were 10 cases showing multiple infection, hence the number of types identified is greater that the number of cases. Percentages indicate the proportion of cases that tested positive for a given type.

*the HPV 44 probe cross-hybridizes to HPV 55, hence these types are reported together. 